\title{
DETERMINING THE LINK BETWEEN INTERNATIONALIZATION AND BUSINESS PERFORMANCE OF SMES
}

\author{
Mihaela Mikić, Dinko Primorac, Goran Kozina
}

Preliminary notes

Internationalization represents an expansion of economic activity beyond the domicile economy, and it is reflected by quantitative changes and more extensive geographical organization of economic activity. In this paper internalization is defined by all aspects of the international activities, including export and import activities. Particularly interesting aspect of internationalization represents the internationalization of SMEs which is still insufficiently explored. Analysis of internationalization in this paper is based on business strategy approach, i.e. internal and external business factors. The business success in this paper is examined using a multidimensional approach, i.e. various dimensions of business success: financial business and organizational performance. Results of analysis of conducted empirical research by multiple linear regression analysis confirmed that internationalization has a positive impact on business performance of SMEs. By integrating different types of connections and structural elements of internationalization and their quantitative examination of the small business sector, this paper thesis presents significant empirical contribution.

Keywords: business performance; Croatia; internationalization; SMEs

Preispitivanje veze između internacionalizacije i uspješnosti poslovanja malih i srednjih poduzeća

Prethodno priopćenje

Internacionalizacija predstavlja širenje ekonomske aktivnosti izvan granica domicilne ekonomije, što se reflektira kvantitativnim promjenama koje dalje vode ekstenzivnijoj geografskoj organizaciji ekonomske aktivnosti. U ovom radu internacionalizacija se sagledava s aspekta svih međunarodnih aktivnosti poduzeća, odnosno izvoznih i uvoznih aktivnosti. Posebno zanimljivi aspekt internacionalizacije predstavlja internacionalizacija malih i srednjih poduzeća koja je još uvijek u u literaturi nedovoljno istražena. Analiza internacionalizacije u ovom radu temelji se na pristupu poslovne strategije, odnosno internim i eksternim faktorima poslovanja. Uspješnost poslovanja poduzeća sagledava se $\mathrm{s}$ aspekta multidimenzionalnog pristupa, odnosno sagledavanjem različitih dimenzija uspješnosti poslovanja: financijske, poslovne i organizacijske uspješnosti. Rezultati analize empirijskog istraživanja provođenjem višestruke linearne regresijske analize potvrdili su kako internacionalizacija ima pozitivan utjecaj na uspješnost poslovanja malih i srednjih poduzeća. Integriranjem različitih vrsta veza i strukturalnih elemenata internacionalizacije te njihovim kvantitativnim ispitivanjem na sektoru malog gospodarstva, ostvaren je značajan empirijski doprinos.

Ključne riječi: Hrvatska; internacionalizacija; mala i srednja poduzeća; poslovna uspješnost

\section{Introduction}

Internationalization is an expansion of economic activity beyond the borders of the domicile economy, which is reflected by quantitative changes that lead further to more extensive geographical organization of economic activity. Internationalization is also one of the basic elements of globalization which also includes the functional integration of internationally dislocated activities and is reflected primarily in qualitative changes in the organization of economic activity [8].

In the first approach internationalization is seen as explicitly export-orientated activity of the enterprise, which includes export, international licenses and franchises, and direct foreign investments. As the export presents the main form of internationalization of SMEs $[34,10]$, this approach focuses on the differences between exporters and non-exporters, export barriers, strategy performances in foreign markets, etc.

Second approach includes both export and import activities of the company and considers the internalization as a set of international activities which includes relationships with suppliers and with customers located outside the boundaries of the domicile economy by using structural and performance indicators. Second approach to defining the concept of internationalization will be the subject of this paper.

The origins of the internationalization of SMEs can be found in the political, technological and economic changes. The establishment of the World Trade Organization (WTO) has led to the liberalization of international trade conditions by reducing obstacles to international trade, such as tariffs, subsidies, etc. The liberalization as a process helped to create a single market, which forced SMEs that want to survive in the market to engage in international competition.

Technology has significantly improved the access to information and the development of telecommunications has enabled the management of geographically dislocated production. Political changes and the reduction in the prices of transport and communication have led to the internationalization of the production structure and increasing international competition. To deal with the challenges of internationalization, entrepreneurs and managers of small and medium-sized enterprises must be aware of the growing competition not only in foreign, but also domestic market.

Internationalization represents an important aspect of maximizing business opportunity, and in the last decades has become a tool of achieving the business success of SMEs [18, 28, 29].

With increasing competition in domestic markets SMEs realized the need to find the new alternatives to solve the problem of competitiveness. Most enterprises got into the process of internationalization to rationalize operating expenses, or to seek for more favourable suppliers outside the boundaries of the domicile economy. Committed to reduce costs, on foreign markets these companies found not only suppliers but labour, capital, technology and other production factors.

On the other hand, many SMEs confronted with shortage of product life cycle searched for a market where 
their products and/or services are still competitive and where demand for them still exists. Companies with a narrow niche production decided to enter the process of internationalization to reduce unit cost and achieve better business performance by increasing production.

By leveraging the complementary resources and opportunities owned by foreign companies from developed economies, local small and medium enterprises are able to improve their competitive advantage and business results. By the access to competent foreign partners, local businesses can overcome the inadequacy of production capacity and take advantage of institutional support.

\section{Literature review and hypothesis}

Research on internationalization of SMEs recently captured the interest of many scientists [24, 16, 1, 25]. Common to mentioned researches is finding that SMEs are able to exploit global market opportunities and to do that faster and more efficiently. Exactly the impact of internationalization on business performance becomes the central theme of the debate in the field of international entrepreneurship [8,35].

In literature it is possible to notice two streams of research. The first stream is focused on international entrepreneurial venture, while the other is focused on small enterprises internationalization. In both cases scientists have perceived costs and benefits of internationalization [2, 35]. Previous researches were focused specifically on the processes of exports and export efficacy [7, 21], while today scientists are more focused on research not only in exports but a wide range of internationalization process [5].

The overview of the literature shows that in the last 40 years scientists have been trying to understand the relationship between internationalization and business performance. The variety of theoretical perspectives and frameworks like for example the impact of foreign direct investment $[12,32]$, the theory of multinational enterprises [11] and organizational learning perspective [27] only contributed to the development of this area.

Although the mentioned problem is central to entrepreneurs $[6,24,5]$ there is only a small number of researches focused on the impact of the internationalization on the business performance. The reason for this is in the difficulties that appear in collecting and getting detailed information on foreign investments of small enterprises, as well as business performance indicators. As entrepreneurs are not obligated to give this information, they usually are not available to the public.

The first studies in the 1970s and 1980s overview only the positive effects of internationalization on enterprise underlining the linear relationship between the process of internationalization and business performance [12]. Later studies in the 1980s and 1990s suggested the inverted $\mathrm{J}$ curve relationship between internationalization and business performance, underlining that there is a point after which the international spread of activities becomes a burden for existing company [11]. But in the same time the other group of scientists has found evidence in support of the thesis that the mentioned relationship is in form of $U[3,27]$, while the third group came to the conclusion that the mentioned relationship is in inverted $U$ form [14]. The most recent studies have resulted by the $\mathrm{S}$ form of the mentioned relationship [4, 19].

Among recent researches should be mentioned the one by authors in [15] who claimed that the business performance is determined by access to information of foreign market, respecting the competitive strategy of enterprise. Authors in [15] underline that entrepreneurial orientation, technological leadership and differentiation strategy are the key to superior international success. The early internationalization of the enterprise decreases the risk of its existence by increasing the sales income [30]. Mentioned is the result of three factors: the age of the enterprise, experience of the management and the access to resources.

Although the results of most studies are generated in big multinational companies, the connection between internationalization and business performance is in the same way complex and unconvincing in the meaning of SMEs, especially within early internationalized enterprises [2, 36, 19, 22].

Beside the problem of the connection form between internationalization and business performance it should be underlined that the mentioned studies were focused specifically on the export activities of the enterprise, ignoring the import component of internationalization.

Exactly these conflicting results are the challenge and interesting area of research, with emphasis that the special challenge is the complexity of the process of internationalization of SMEs as well as defining those categories that do not achieve direct impact on business performance.

Consequently, the following hypothesis can be formulated: Internationalization has positive impact on business performance of SMEs.

\section{Methodology \\ 3.1 Sample}

The population of this study consists of all Croatian manufacturing SMEs. A small enterprise is defined as an enterprise with up to 50 employees, while the mediumsized enterprise employs 50-250 employees. Size data of the company are available in the Register of the Croatian Chamber of Commerce.

Manufacturing SMEs are the subject of this study because of its high correlation to other industries and because most of the previous researches have shown that most manufacturing companies have access to more capital than service companies and therefore are more internationalized [26].

The original sample of this empirical research is composed of 800 small and medium-sized manufacturing enterprises. The sample was selected randomly and the sample corresponds to the population, i.e. company distribution by business activity is the same in the sample as in general population. The survey was answered by 88 respondents which is enough to conduct multiple linear regression.

Regarding the business size of the respondents, $54,55 \%(n=48)$ were small firms and 45,45\% $(n=40)$ 
medium sized firms. Their most common business activities as shown in Fig. 1 are: manufacture - C (46\%), water supply and waste management - E (17,5\%), agriculture, foresting and fishing - A (10\%) and construction $-\mathrm{F}(8 \%)$. On average, questioned entrepreneurs have business experience of 16,68 years. They entered entrepreneurship with 3,31 years of business experience on average.

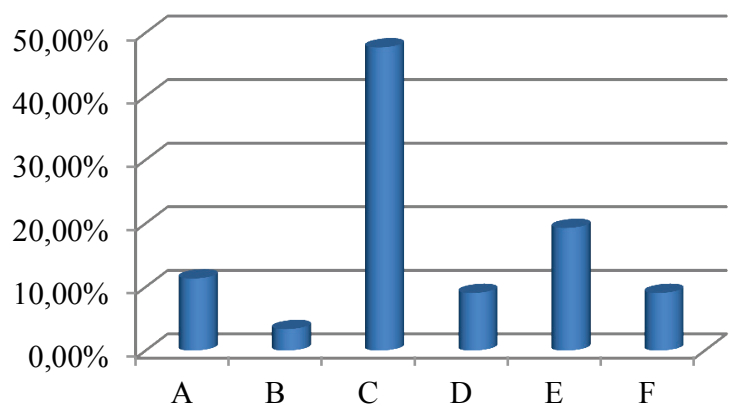

Figure 1 Business distribution according to business activity

Regarding the level of internationalization of the respondents, $64 \%$ are active in international relating, i.e. have export and/or import activities, and $36 \%$ are doing business specifically within Croatian territory. By detailed reassessment of the degree Croatian SMEs are internationalized, it is possible to spot that most, around $47 \%$, enterprises belong to the group of import-export oriented enterprise i.e. they have both export and import activities. About $13 \%$ enterprises are only import oriented, while only about $5 \%$ of Croatian SMEs are export oriented. The last category, export-oriented enterprise represents enterprises that find all of needed raw materials, technology and human capital in the domestic economy and place their finished or semifinished products on foreign market and because of that they are the most interesting category of enterprises which should be in the centre of economic policy of each Government. By promoting and encouraging such enterprises it is possible to accomplish more significant rates of economic growth.

It is interesting that Croatian internationalized SMEs usually exported finished products in $76 \%$ of cases, and imported raw materials in $64 \%$ of cases. This indicates the positive trends in the business activity of internationalized SMEs, and it can also be proven by analysis of the trend of their trade balance.

If we look at the distribution of non-internationalized enterprises according to business activity we can see that most companies are in the sector of water supply, sewerage and waste management, which is in harmony with the nature of their activities. Most companies in this economic sector are still state-owned, and many of them have a monopoly position in the market. Interestingly, the export-oriented companies and import-oriented enterprises are in the economic sector of electricity supply, gas, steam and air conditioning, but due to a small sample it is not possible to make meaningful conclusions. Companies with both import and export activities are most common in the manufacturing industry (almost $73,2 \%$ ). If the above information is connected to the previous analysis it can be established that import-export companies import raw materials which are then processed and sold on foreign markets in the form of finished or intermediate products.

Croatian SMEs mostly export to neighbouring countries, countries of former Yugoslavia. The reasons for this are historical ties, similarity of language and similarity in the way of doing business. The second group of export countries for Croatian small and medium manufacturing enterprises includes Italy, Austria and Germany. On average the surveyed Croatian exporters sell products in 6,69 countries.

The analysis of import activities show that Croatian small and medium-sized enterprises usually import from Germany, Italy and Austria. Interestingly, while the Croatian market is flooded with products from China, Malaysia and Taiwan, China and Malaysia (Taiwan is not listed) make up less than 5\% in the structure of countries from which Croatian SMEs import. This indicates that the majority of products from these countries to Croatia do not come directly but through an intermediary in Germany, Italy and Austria. On average the questioned Croatian SMEs have 11,16 foreign suppliers.

\subsection{Variables}

Since in this paper internationalization is defined as all firm's import and export activities it was necessary to adjust the existing indicators of internationalization in large enterprises [9, 31]. As an indicator of internationalization, internationalization index is used and it consists of structural indicators and performance indicators. Structural indicators include the following indicators:

- the number of countries where the company operates,

- the number of international strategic alliances,

- the number of international franchises,

- the number or proportion of foreign suppliers.

Indicators of performance include the following:

- exports income,

- share of export revenue in total revenue,

- liabilities to foreign suppliers

- share of foreign supplier liability in total supplier liability.

As the performance indicators consist of data that entrepreneurs/managers are not willing to voluntarily give, subjective measures of performance were used, i.e. the instrument of success weighted average [6], which is actually a derivative of the instrument developed by authors in [13].

According to given method questioners are asked to determine level of significance from 1 to $5(1=$ strongly insignificant, $5=$ strongly significant) which every indicator represents for their company, and then in the same manner to determine the degree of satisfaction with the results achieved by individual indicator. Performance index is calculated in the form of weighted average by multiplying the assessment of significance and satisfaction of certain criteria.

Business success is defined as the achievement of above-average returns over a certain number of years. Business success can also be defined as the ability to 
achieve the listed objectives in the form of customer satisfaction, market share, and to achieve a certain level of revenue and profits. Within manufacturing enterprises, business efficiency is often defined as the ability to produce the target output to meet the needs of stakeholders. The very definition of business success depends on the needs and preferences of different interest groups within and outside the company.

In this paper business performance is defined by using multidimensional approach, i.e. we used three dimensions of business performance [8]:

- financial performance,

- operational performance and

- organizational performance.

Financial performance presents the key of business effectiveness, and it is significant, but not enough for defining overall business performance [23]. In calculating financial performance of Croatian SMEs the following indicators were used: total profit, ROA and ROE.

Operational performance measures market oriented indicators and consists of two types of indicators. First group is focused on current business position and includes growth of total income and market share. Second group is focused on future business position and is measured by new product development and diversification. New product development and application of new products are the result of a firm's innovation process. Innovation as a byproduct of investments in research and development represents the backbone for the creation of competitive advantage. The concept of diversification indicates the growth of the company through its entry into the activities which are different from its core business activity. This strategy is basically more risky than other growth strategies, as the company gets involved into a completely new production and new markets without previous experience

Organizational performance is closely connected with stakeholders and includes: employees' satisfaction, business quality and social responsibility. This dimension of business performance can also be divided into two categories: indicators of quality (product quality, customer satisfaction and overall quality level) and indicators of social responsibility (environmental responsibility and community responsibility). As organizational performance of Croatian SMEs in this paper these indicators were used: employees' satisfaction, quality and social responsibility.

As in the case of SMEs there are no available objective data about their business performance because they are not part of official government statistics, subjective measures were used. These measures are the same as in the case of internationalization (Indicator of performance).

\subsection{Analysis}

Multiple linear regression method is used for the prediction of the dependent variable on the basis of the insights that can be obtained from a number of independent variables and for determining the nature and relationship between these variables and the variables used to measure the quantitative scale.
Standard methods of multiple linear regression are used and all independent variables entered into the regression equation simultaneously in order to explore the relationship between the entire set of independent variables and the dependent variable. For the evaluation of the strength of relations among variables the regression coefficients and t-test are used.

\section{Results}

The outcome of a multiple linear regression using the method of least squares (Tab. 1) shows estimated equation model of the impact of internationalization on enterprise's business performance as follows:

$\bar{Y}=3,04+0,39 \times S P I+0,39 \times P I I$

$\bar{Y}=$ business performance (index)

$S F I=$ structural indicators of internationalization

$P I I=$ performance indicators of internationalization

Table 1 The outcomes of the multiple linear regression factors)

\begin{tabular}{|c|c|c|c|c|}
\hline$N=88$ & Coefficient & $\begin{array}{c}\text { Standard } \\
\text { deviation }\end{array}$ & $t(85)$ & $p$-level \\
\hline$\alpha$ & 3,035383 & 0,095049 & 31,93501 & 0,000000 \\
\hline$S F I$ & 0,388206 & 0,208337 & 1,86335 & 0,065866 \\
\hline$P I I$ & 0,390144 & 0,179050 & 2,17897 & 0,032102 \\
\hline
\end{tabular}

\begin{tabular}{|l|c|}
\hline \multicolumn{1}{|c|}{ Statistics } & Value \\
\hline Multiple $R$ & 0,44254 \\
\hline Multiple $R^{2}$ & 0,19584 \\
\hline Adjusted $R^{2}$ & 0,17692 \\
\hline$F(2,85)$ & 10,35025 \\
\hline$p$ & 0,00009 \\
\hline Std.Err. of Estimate & 0,66479 \\
\hline
\end{tabular}

Results show (Tab. 1) that there is positive and very significant influence of internationalization on business performance $(F(2,85)=10,35025 ; p<0,001)$. Structural indicators of internationalization, as a first order variable, have a positive effect on business performance $\left(\beta_{1}=0,39\right.$; $p<0,07)$. Performance indicators of internationalization also have a positive effect on business performance $\left(\beta_{2}=0,39 ; p<0,04\right)$.

The contribution of internationalization to the explanation of business performance is satisfactory, explains $19,58 \%$ of the variance of internationalization, in the population it would be about $17,69 \%$. Although this figure seems relatively small it should be noted that internationalization is only one of the predictors of business performance, and in this case it means that internationalization affects business performance statistically significant, but there are still plenty of other factors that also affect business operations and in this case were not taken into account.

Regardless of the value of $R^{2}$, the model of the impact of internationalization on enterprise's business performance is highly significant $(\mathrm{p}<0,001)$.

Table 2 Correlation matrix of individual indicators of internationalization

\begin{tabular}{|c|c|c|}
\hline Variable & SPI & PII \\
\hline$S P I$ & 1,000000 & 0,604722 \\
\hline$P I I$ & 0,604722 & 1,000000 \\
\hline
\end{tabular}


After examining the correlation matrix of internationalization variables it can be concluded that there is a significant correlation between the variables structural indicators of internationalization and performance indicators of internationalization (table 2).

Since the value of the Durbin-Watson is $d=$ 1,891392, it can be concluded that significant autocorrelation of the first order is not present. After conducting Cross Term White test, to test heteroscedasticity, it can be concluded that there is homoscedasticity with the level of significance of $1 \%$.

\section{Conclusion}

The internationalization has a positive impact on the business performance of SMEs. This has been demonstrated by implementing a multiple linear regression analysis whose results prove that internationalization represents an important aspect in maximizing business opportunities and has positive impact on business performance. Internationalization, according to this analysis, has a positive impact on all spheres of business performance, ie. financial, operational and organizational performance.

Regarding the results from conducted research we can say that internationalization represents an important aspect of maximizing business opportunity for Croatian small and medium sized manufacturing enterprises.

In this study the internationalization is defined as the sum of all international business activities, both export or import activities. This definition distinguishes this study and its conclusions from previously conducted researches. Results of empirical research suggest that Croatian small and medium sized enterprises in the field of manufacturing involved in international activities generate higher levels of business performance than the enterprises that are specifically oriented to only domestic market.

Also, a higher degree of company internationalization and increase in the volume of international activities lead to achieving better business results. By integrating the different types of connections and structural elements of internationalization and individual internationalization indicators of enterprises, and their quantitative examination in the SMEs manufacture sector, there has been considerable empirical contribution, since previous work mainly focused on the export activity of large enterprises. In addition, this is the first time that such research was conducted in Croatia and therefore it can be said that it includes the specifics of the social, economic and cultural environment.

Certain limitation of this research is the size of the sample. Although the sample size and the rate of return seem technically satisfactory, future research should be conducted on a larger sample.

Findings of the positive impact of the internationalization of the business performance of SMEs may be a guideline for Croatian small and medium sized enterprises in conducting international activities with the aim at improving the current level of performance and ensuring the long-term competitive position on both domestic and global market.
6 References

[1] Autio, E. Creative Tension: The significance of Ben Oviatt's and Patrica McDougall's article „Toward a Theory of International New Ventures. // Journal of International Business studies. 36, 1(2005), pp. 9-19. DOI: $10.1057 /$ palgrave.jibs. 8400117

[2] Autio, E.; Sapienza, H. J.; Almeida, J. G. Effects of Age at Entry, Knowledge Intensity and Imitability on International Growth. // Academy of Management Journal. 43, 5(2000), pp. 909-924.

[3] Capar, N.; Kotabe, M. The Relationship between International Diversification and Performance in Service Firms. // Journal of International Business Studies. 14, 4(2003), pp. 345-355. DOI: 10.1057/palgrave.jibs.8400036

[4] Contractor, F. J.; Kuncu, S. K.; Chin, C. H. A Three Stage Theory of International Expansion: The Link between Multinationality and Performance in the Service Sector. // Journal of International Business Studies. 34, (2003), pp. 5 18. DOI: $10.1057 /$ palgrave.jibs. 8400003

[5] Coviello, N. E.; McAuley, A. Internationalisation and the Smaller Firm: A Review of Contemporary Empirical Work. // Management International Review. 39, 3(1999), pp. 223257.

[6] Covin, J. G.; Slevin, D. P. A Conceptual Model of Entrepreneurial Firm Behaviour. // Entrepreneurship: Theory and Practice. 16, 1(1991), pp. 7-25.

[7] Dichtl, E.; Leibold, M.; Köglmayr, H. G.; Müeller, S. The Export-Decision of Small and Medium Sized Firm: A Review. // Management International Review. 24, 2(1984), pp. 23-40.

[8] Dicken, P. Global Shift: Reshaping the Global Economy Map in the 21st Century, Fourth Edition, Guilford, London, 2003.

[9] Dorrenbacher, C. Measuring Corporate Internationalization: A Review of Measurement Concepts and Their Use. // Intereconomics. The Web Version (2000), http://www.econstor.eu $\quad(13.10 .2014)$ DOI: 10.1007/BF02927197

[10] Eusebio, R.; Andreu, J. L.; Belbeze, M. Internal Key Factors in Export Performance: A Comparative Analysis in the Italian and Spanish Textile-Clothing Sector (part 1). // Journal of Fashion Marketing and Management. 11, 1(2007), pp. 9-23. DOI: 10.1108/13612020710734373

[11] Gomes, L; Ramaswamy, K. An Empirical Examination of the Form of the Relationship Between Multinationality and Performance. // Journal of International Business Studies. 30, (1999), pp. 173-188. DOI: 10.1057/palgrave.jibs.8490065

[12] Grant, R. M. Multinationality and Performance among British Manufacturing Companies, Journal of International Business Studies, 18, 3 (1987), pp. 79-89. DOl: 10.1057/palgrave.jibs. 8490413

[13] Gupta, A. K.; Govindarajan, V. Business Unit Strategy, Managerial Characteristics and Business Unit Effectiveness at Strategy Implementation. // Academy of Management Journal. 27, (1984), pp. 25-41. DOI: 10.2307/255955

[14] Hitt, M. A.; Hoskisson, R. E.; Kim, H. International Diversification: Effects on Innovation and Firm Performance. // Academy of Management Journal. 40, (1997), pp. 767-798. DOI: 10.2307/256948

[15] Julien, P. A.; Ramangalaby, C. Competitive Strategy and Performance of Exporting SMEs: An Empirical Investigation of the Impact of Their Export Information Search and Competencies. // Entrepreneurship Theory and Practice. 27, 3(2003), pp. 227-245. DOI: 10.1111/15408520.00013

[16] Knight, G.; Cavusgil, S. T. The Born Global Firm: A Challenge to Traditional Internationalization Theory. // Advances in International Marketing. 8, (1996), pp. 11 -26. 
[17] Knight, G.; Cavusigil, S. Innovation, Organizational Capabilities and the Born-Global Firm. // Journal of International Business Studies. 35, 2(2004), pp. 124-141. DOI: $10.1057 /$ palgrave.jibs.8400071

[18] Knowles, D.; Mughan, T.; Lloyd-Reason, L. Foreign Language Use among Decision-Makers of Successfully Internationalized SMEs: Questioning the Language Training Paradigm. // Journal of Small Business and Enterprise Development. 13, 4(2006), pp. 620-641. DOI: 10.1108/14626000610705787

[19] Lu, J. W.; Beamish, P. W. The Internalization and Performance of SMEs. // Strategic Management Journal. 22, (2001), pp. 565-586. DOI: 10.1002/smj.184

[20] McAuley, A. Entrepreneurial Instant Exporters in the Scotttish Arts and Crafts Sector. // Journal of International Marketing. 7, 4(1999), pp. 67-82.

[21] Miesenbock, K. J. Small Business and Exporting: A Literature Review. // International Small Business Journal. 6, 2(1988), pp. 42-61. DOI: 10.1177/026624268800600204

[22] Moen, Ø. The Born Globals. // International Marketing Review. 19, 2(2002), pp. 156-175. DOl: $10.1108 / 0265133021042501.1$

[23] Murphy, G. B.; Trailer, J. W.; Hill R. C. Measuring Performance in Entrepreneurship Research. // Journal of Business Research. 36, (1996), pp. 15-23. DOI: 10.1016/0148-2963(95)00159-X

[24] Oviatt, B.; McDougall, P. Towards a Theory of International New Ventures. // Journal of International Business Studies. 25, 1(1994), pp. 45-64. DOI: 10.1057/palgrave.jibs. 8400128

[25] Rialp, A.; Rialp, J.; Urbano, D.; Vaillant, Y. The BornGlobal Phenomenon: A Comparative Case Study Research. // Journal of International Entrepreneurship. 3, 2(2005), pp. 133-171. DOI: 10.1007/s10843-005-4202-7

[26] Roberts, J. The Internationalisation of Business Service Firms: A Stages Approach. // The Service Industries Journal, 19, 4(1999), pp. 68-88. DOl: $10.1080 / 02642069900000045$

[27] Ruigrok, W.; Wagner, H. Internationalization and Performance: An Organizational Learning Perspective. // Management International Review. 43, (2003), pp. 63-83.

[28] Rundh, B. International Marketing Behaviour amongst Exporting Firms. // European Journal of Marketing. 41, 1/2(2007), pp. 181-198. DOI: 10.1108/03090560710718175

[29] Saixing, Z.; Xie, X. M.; Tam, C. M.; Wan, T. W. Relationships between Business Factors and Performance in Internationalization: An Empirical Study in China. // Management Decision. 47, 2(2009), pp. 308-329. DOl: 10.1108/00251740910938939

[30] Sapienza, H.; Autio, E.; George, G.; Zahra, S. A. A Capabilities Perspective on the Effects of Early Internationalization on Firms Firm Survival and Growth. // Academy of Management Reviews. 31, 4(2006), pp. 914933. DOI: $10.5465 / A M R .2006 .22527465$

[31] Sullivan, D. Measuring the Degree of Internationalization of a Firm. // Journal of International Business Studies. 25, 2(1996), pp. 355-342. DOI: 10.1057/palgrave.jibs.8490203

[32] Tallman, S.; Li, J. Effects of International Diversity and Product Diversity on the Performance of Multinational Firms. // Academy of Management Journal. 39, (1996), pp. 179-196. DOI: $10.2307 / 256635$

[33] Venkatraman, N.; Ramanujam, V. Measurement of Business Performance in Strategy Research: A Comparison of Approaches. // Academy of Management Review. 11, (1986), pp. 801-814. DOI: 10.5465/AMR.1986.4283976

[34] Westhead, P. International Opportunity Exploitation Behaviour Reported by "Types" of Firms Relating to Exporting Experience. // Journal of Small Business and Enterprise Development. 15, 3(2008), pp. 431-456. DOI: $10.1108 / 14626000810892274$
[35] Zahra, S. A Theory of International New Ventures: A Decade of Research. // Journal of International Business Studies. 36, 1(2005), pp. 20-28. DOI: 10.1057/palgrave.jibs. 8400118

[36] Zahra, S. A.; Ireland, R. D.; Hitt, M. A. International Expansion by New Venture Firms: International Diversity, Mode of Market Entry, Technological Learning and Performance. // Academy of Management Journal. 43, (2000), pp. 925-950. DOI: 10.2307/1556420

\section{Authors' addresses \\ Mihaela Mikić, PhD \\ University of Zagreb \\ Faculty of Economics and Business \\ Trg J. F. Kennedyja 6, 10000 Zagreb \\ mihaela.mikic@efzg.hr}

Dinko Primorac, Assistant Professor, PhD

University North

Trg dr. Žarka Dolinara 1, 48000 Koprivnica, Croatia dinko.primorac@unin.hr

Goran Kozina, Professor, PhD

University North

Trg dr. Žarka Dolinara 1, 48000 Koprivnica, Croatia goran.kozina@unin.hr 